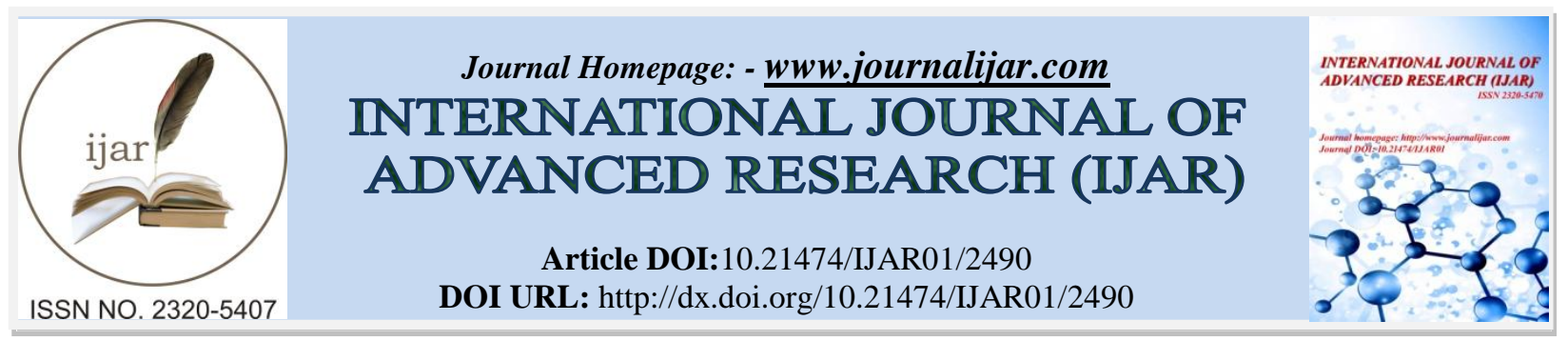

RESEARCH ARTICLE

\title{
TOURIST CIRCUIT PLANNING FOR GREATER HYDERABADCLUSTER IDENTIFICATION - USING GIS
}

Dr. Deepthi Guntuka, Dr. Anand Gopagani and Prof. Vijaya Bhole. Department of Geography, Osmania University, Hyderabad-500007

\section{Manuscript Info}

Manuscript History

Received: 23 October 2016

Final Accepted: 21 November 2016

Published: December 2016

\section{Abstract}

Tourism sector is the world's leading industry in terms of revenue generation with an approximate value of U.S $\$ 4$ trillion plus and still growing. It is the foremost export earner industry and comprises around 11 percent of the world's GDP. The success of tourism in any country depends on the ability to adequately develop, manage and market the tourism services and activities in that country. Large cities are already tourist centers and have many facilities are marketed properly. Generally tourism is considered as the activities of persons travelling to and in place outside their usual environment. Urban Tourism is an integral part of urban economy, urban Environment, urban morphology and other aspects of urban studies. The tourist potential of Hyderabad is reflected by large number of tourist spots. These tourist spots are located in different parts of the city. They are located in different surroundings. For optimization of sightseeing of tourist places, information regarding location of other tourist spots in its vicinity is very useful. It is thus seen that, location visualization and characterization of tourist cluster provided large volume of information which is useful not only for the tourist, but also for tour operator, tourist planner, tourism department etc. Such type of analysis can be replicated in other urban tourist places.

Copy Right, IJAR, 2016,. All rights reserved.

\section{Introduction:-}

Tourism is a composite of activities, facilities, services and industries that deliver a travel experience, that is, transportation, accommodation, eating and drinking establishments, entertainment, recreation, historical and cultural experience, destination attractions, shopping and other services available to travelers away from home (Dondo et al, 2002). The definition suggests that the tourism business is not confined to a single service rather it involves a large variety of diverse, exclusive and specialized services that can be provided by different groups. Tourism sector is the world's leading industry in terms of revenue generation with an approximate value of U.S \$4 trillion plus and still growing at an average rate of 10 percent per annum (kumar, 2003). It is the foremost export earner industry and comprises around 11 percent of the world's GDP (Gross Demestic Product) (Law, 1992) (Staab \& Werthner, 2002). With such a huge share it will have a great impact on the economies of countries worldwide. According to Alipour and Kilic (2003), developing countries can utilize the opportunities lying with the tourism sector and attain economic prosperity. The flow of tourists in a country increases the foreign currency reserves, which can be a boost to a country's economy. Generally tourism is considered as the activities of persons travelling to and in place outside their usual environment for not more than one consecutive year for leisure, business and other purposes. Urban tourism is 
defined as "the set of tourist resources or activities located in towns and cities and offered to visitors from elsewhere." or "Urban tourism is the practice of taking a vacation and visiting an inner-city area". Different scholars have expressed various views in defining the characteristics, nature and scope of urban tourism.

\section{Leisure / recreation/ travel and tourism:-}

Tourism, Recreation, leisure is generally seen as a set of interrelated \& overlapping concepts. Leisure is defined as a period of time, activity state of mind in which choice is the dominant feature $\&$ leisure is perceived as opposite to work or residual time. Leisure as a qualitative concept in which leisure activity take on near only within the concept of individual perception Leisure is therefore seen as time over which an individual exercises choice \& under takes activity in free time.

A common factor in tourism definitions is travel. Since tourism involves travel it requires more discretionary time than recreational activity. While most tourism is recreational in nature, some tourism such as business professional and personal travel is not associated with recreation. Recreation falls entirely within the ambit of leisure since it is associated with free or discretionary time which leads to rejuvenation of body \& mind. Tourism orbit extends beyond recreation to become associated with social activity business trips. Leisure and recreation are both crucial components of balanced health and life style. Leisure is associated with time when people can do what they want do. Recreation and leisure play is important role in social wellbeing. Towns \& cities held special foci for the geographers, since their evolution as places where people live, work, shop \& engage in leisure. Since classical times, town \& cities have performed tourism \& leisure functions and therefore such places have a long history as places of tourism. Tourism is recognized as world's largest industry. Cities are both tourist destination \& tourist generating areas.

\section{Study Area:-}

Hyderabad, the capital of Telangana is located between $17^{\circ} 15^{\prime} \mathrm{N}$ to $17^{\circ} 28^{\prime} \mathrm{N}$ and $78^{\circ}-22^{\prime} 30^{\prime \prime} \mathrm{E}$ to $78^{\circ} 32^{\prime} 33^{\prime \prime} \mathrm{E}$. It is located in Sothern part of Telangana and surrounded by RangaReddy district. It is one of the fastest growing metropolises of India. The elevation of Hyderabad ranges between $350 \mathrm{~m}$ to $540 \mathrm{~m}$ above MSL. The tourist potential of Hyderabad is reflected by large number of tourist spots. These tourist spots are located in different parts of the city. The Greater Hyderabad Municipal Corporation (GHMC) covers Municipal Corporation of Hyderabad \& surrounding municipalities. The tourist spots in GHMC are widely scattered. To bring out the spatial perspective, distribution of these tourist spots in the GHMC area is divided into four distinct morphological zones as Hyderabad south, Hyderabad north, Secundrabad and surrounding municipalities. Hyderabad is known for its rich history, culture and architecture representing it's unique character as a meeting point for North \& South India. It is also known as the "The city of pearls" and "city of Nizams". It has also got the distinction of being called as "second silicon valley of India" and "cultural metro of India". Hyderabad city has grown in leaps and bounds in all directions during different phases of its historical evolution merging surrounding municipalities. The following municipalities that fell under Rangareddy, Medak districts merged with Municipal Corporation of Hyderabad (MCH) to from Greater Hyderabad Municipal Corporation (GHMC).

The tentacle of urban growth of Hyderabad in terms of spatial extent has witnessed phenomenal development. The impetus for the urban growth is provided by the IT sector. The initiatives like HITEC (Hyderabad Information Technology and Engineering Consultancy) city, the Indian Institute of Information Technology (IIIT), Indian School of Business (ISB) have put Hyderabad on the global map. The HITEC city located in Cyberabad in the north western part of the city has been developed exclusively for housing multinational companies. Hyderabad has a technology park with leading companies like Intergraph, Oracle, IBM, Accenture, Microsoft, Google, Dell etc.

Morphologically, the city of Hyderabad can be divided into

1. Hyderabad South with Charminar as historical core (circle I \& II).

2. Hyderabad North with CBD (circle III, IV, V, VI).

3. Secunderabad (circle VII).

4. Surrounding municipalities in GHMC (circle VII - XVIII).

The city is cosmopolitan in nature and is richly endowed with a variety of cultures and ethnic diversity. While Muslim population is concentrated more in Hyderabad south i.e. old city, Secunderabad has got a more contemporary look with concentration of Anglo Indians. The city of Hyderabad presents an attractive amalgamation 
of old world charm together with the modern architectural edifices built in the Medieval, Moughal, colonial and Indo-Sarcenic styles.

\section{Objectives:-}

1. To Identify and locate the places of tourist interest

2. To Analyse the spatial distribution pattern of tourism sites

3. To identify tourist clusters for the optimization of sightseeing of tourist places

Data base and Methodology:-

The study is based on secondary data which is obtained from Tourism Development Corporation and Greater Hyderabad Municipal Corporation. Mapping and analysis is done in Geographical Information system using Arc GIS. Handheld GPS is used in the location identification of places of tourist interest. For optimal tourism sightseeing prior knowledge about inter distance between various tourist spots is considered as major input in the visitors itenary. Based on agglomeration of tourist spots five major tourist clusters is identified. To derive the nearest neighbor as well as distance between two nearest tourist spots, ArcGIS.10 is used. Based on the input from the nearest neighbor analysis and buffering. To bring out the location/ spatial analysis of tourist spots Nearest Neighbor analysis technique is used to identify the clusters. The distribution of tourist spot in Hyderabad is random. Six major tourist clusters are identified. Keeping in view, the major tourist spot within a cluster, a buffer zone of 100 meter interval is drawn.

Fig 1:- Spatial distribution of tourist spots.

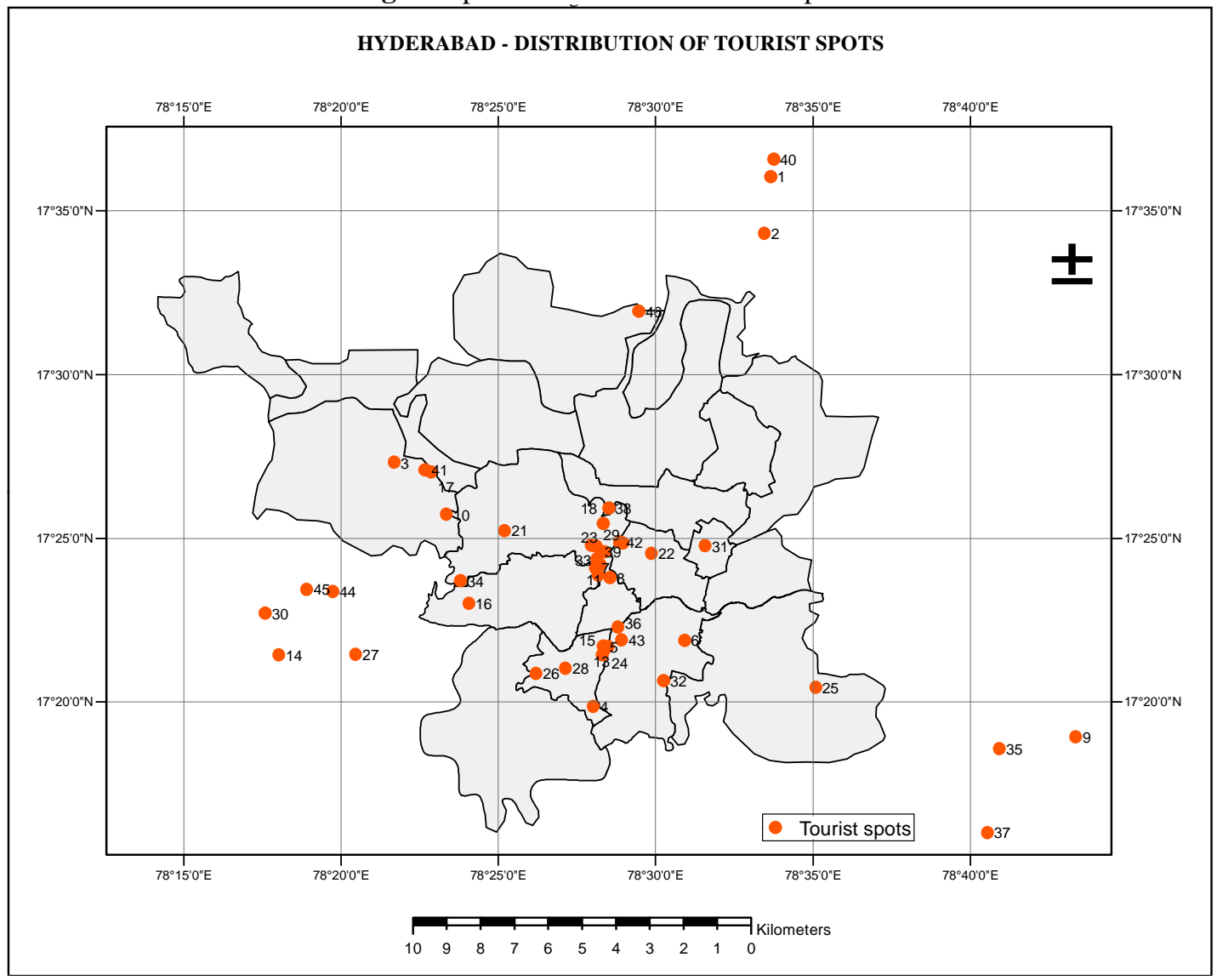

Source: Based on Data from Tourism Department, Government of Telangana

\section{Characteristic of tourist clusters:-}

After identification of the tourist clusters, an attempt is made here to highlight the nature of each cluster. In the Birla mandir cluster, within $100 \mathrm{mt}$ buffer tourist spots are characterized by multiplex \& Imax and parks. It is a zone which is associated the CBD of Hyderabad. In 200-300 mt buffer zone, museums, monuments, planetarium, lakes, parks 
are located. Tourist spots in this cluster are mostly related to leisure and recreation. There only one tourist spot in $300 \mathrm{mt}$ buffer characterized by a park. Tourist spot known for Art/Crafts is located in 400mt buffer.

Table 1:-Hyderabad-Distribution of Clusters.

\begin{tabular}{|l|l|c|}
\hline Name of the cluster & Unique ID & Total \\
\hline Birla mandir & $7,8,11,12,19,23,29,33,39$ & 9 \\
\hline Charminar & $4,5,13,15,24,26,28,36,43$ & 9 \\
\hline Golconda fort & $3,10,16,17,21,34,41$ & 7 \\
\hline Chilukur balaji temple & $14,27,30,44,45$ & 5 \\
\hline Hussain sagar & $18,20,22,31,38,42$ & 6 \\
\hline Ramoji film city & $9,35,37$ & 3 \\
\hline
\end{tabular}

\section{Cluster Analysis:-}

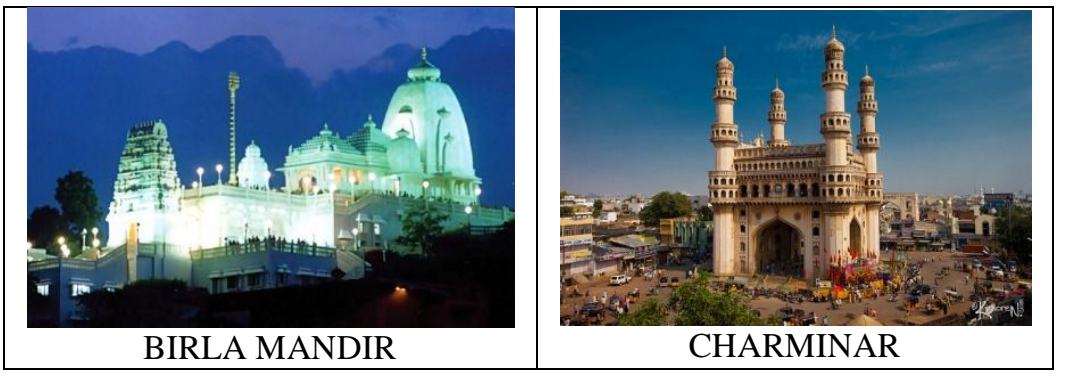

Birla mandir cluster is highly diversified with highest number of tourist spots. Regarding Charminar cluster, the $<100 \mathrm{mt}$ buffer is characterized by retail, shopping, monuments, palaces. This cluster is the part of historic core of the city. World famous Salarjung museum is located in $200 \mathrm{mt}$ buffer zone, whereas $300 \mathrm{mt}$ buffer zone is characterized by park and palaces. The 400 buffer has the presence of tombs and tank. This cluster is characterized mostly by historical/cultural tourist spots.

Fig 2:-

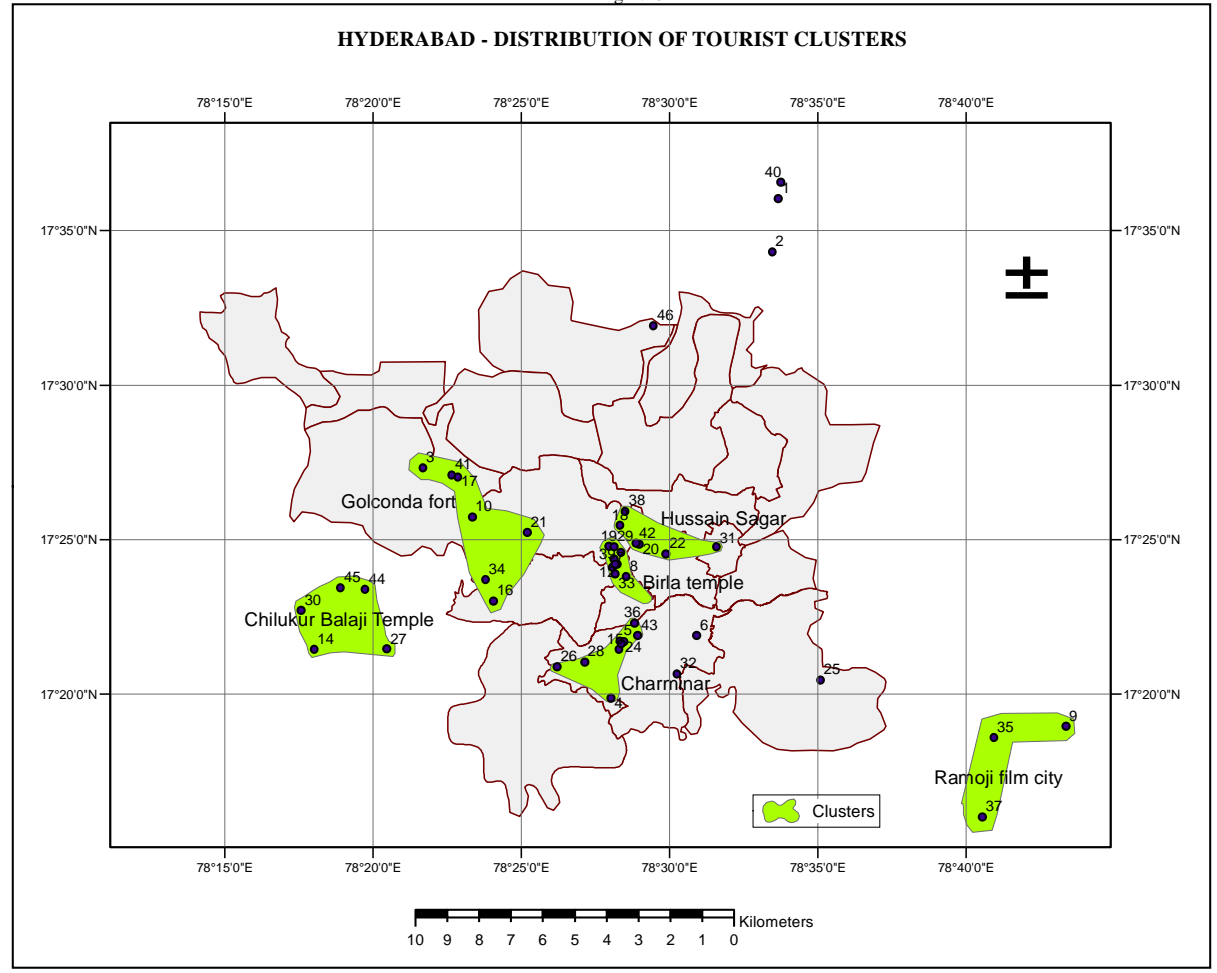

Source: Based on Data from Tourism Department, Government of Telangana 


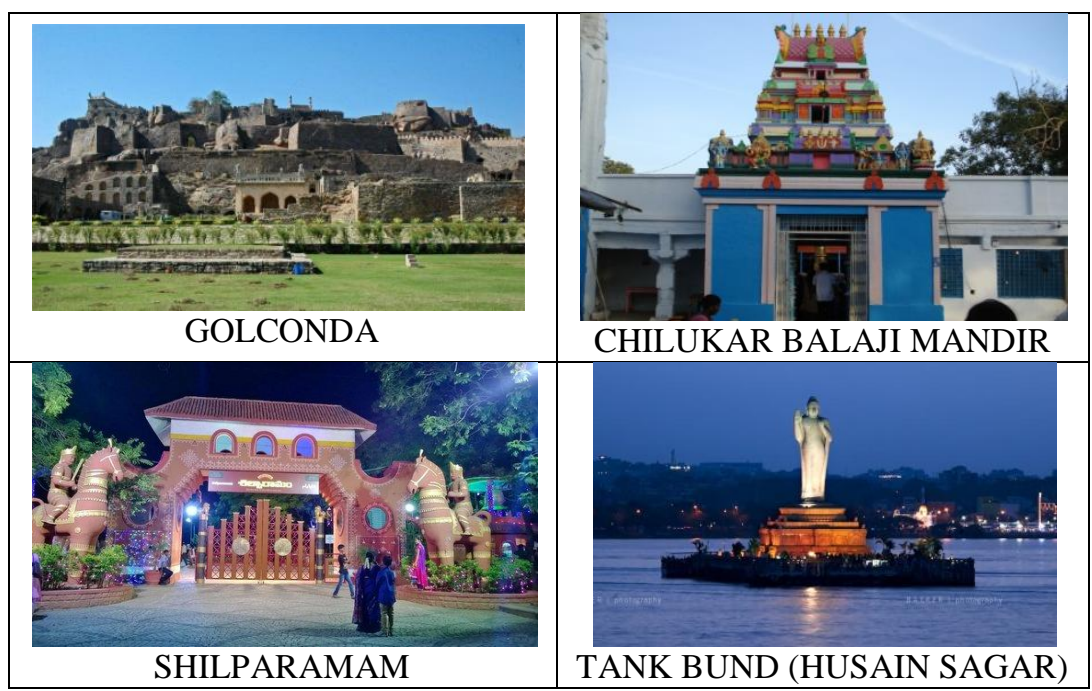

The Golconda cluster is the one which is associated with the oldest part of the city with Golconda fort within 100mt buffer and Qutub shahi tomb in 200mt buffer zone.

The Chilukur Balaji cluster has waterfront tourist spot within 100mt buffer zone and recreational, religious center in $300 \mathrm{mt}$ buffer zone. The Shilparamam cluster is having IT hub and Art \& Craft village within 100-200mt buffer zone. Waterfront tourist spot is located within $300 \mathrm{mt}$ buffer zone.

Hyderabad has the distinction of having a large number tourist spots (46 no.). They are located in different surroundings. For optimization of sightseeing of tourist places, information regarding location of other tourist spots in its vicinity is very useful. The tourist can visit many tourist places if they have the idea regarding neighboring tourist spots. Besides, the tour operators will have an idea in planning the tourist circuit. Keeping this requirement of the tourists an attempt is made here to identify tourist clusters in urban area based on nearest neighbor analysis tool in ArcGIS. The tourist places in Hyderabad are grouped under six major clusters (figure-2). The major tourist spot is considered as the center around which buffer zones of $100 \mathrm{mt}$ interval is drawn. Four circular buffer of 100, 200, $300,400 \mathrm{mt}$ is drawn around the major tourist spot.

\section{Tourist clusters - a spatial perspective:-}

Fig 3:-

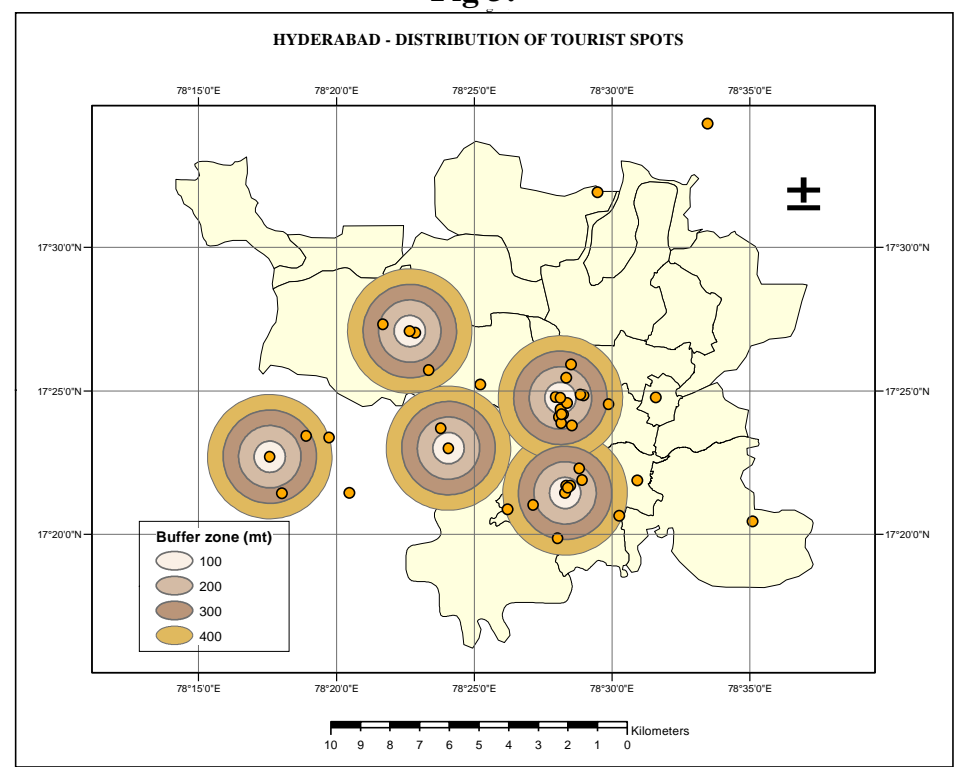

Source: Based on Data from Tourism Department, Government of Telangana 
Based on agglomeration of tourist spots and nearest neighbor statistics, derived from ArcGIS five major tourist clusters is identified with is presented in table-1. The Birla mandir cluster has 14 tourist spots. It has the highest number of places in tourist interest. This cluster is located in the heart of the city, in the vicinity of Tank bund. There only 4 places of tourist spot within 100mt. highest number of tourist spots is located in 100-200 mt buffer zone. Least number of tourist spots is located in 200-300 mt \& 300-400 mt buffer zone.

The second largest cluster is Charminar which has 10 tourist spots. There are 4 tourist spots located in within $100 \mathrm{mt}$ buffer. In the 200, 300, 400mt buffer zone, 6 tourist spots located with two tourist spots in each of these three buffer zone. The Golconda tourist cluster has only two tourist spots, i.e. one in $>100 \mathrm{mt}$ buffer and another between 100 $200 \mathrm{mt}$ buffer.

Table 2:-Hyderabad- Tourist Clusters

\begin{tabular}{|c|c|c|c|c|}
\hline \multirow{2}{*}{ Name of the cluster } & \multicolumn{4}{|c|}{ Distance (in meters) } \\
\cline { 2 - 5 } & $\mathbf{1 0 0}$ & $\mathbf{2 0 0}$ & $\mathbf{3 0 0}$ & 1 \\
\hline Birla mandir & 4 & 8 & 2 & 2 \\
\hline Charminar & 4 & 2 & Nil & Nil \\
\hline Golconda fort & 1 & 1 & 2 & 1 \\
\hline Chilukur balaji temple & 1 & Nil & 1 & Nil \\
\hline Shilparamam & 2 & 1 & $\mathbf{6}$ & $\mathbf{4}$ \\
\hline Total & $\mathbf{1 2}$ & $\mathbf{1 2}$ & & 1 \\
\hline
\end{tabular}

Chilukur Balaji temple cluster has 4 tourist attractions. One tourist spot is located in <100mt buffer. Interestingly, two tourist spots are located in 200-300mt buffer. One tourist center falls in 300-400mt buffer. Shilparamam tourist cluster has also 4 tourist attractions, two in $<100 \mathrm{mt}$ buffer and one each in $200-300 \mathrm{mt}$ and $300-400 \mathrm{mt}$ buffer.

An analysis of tourist cluster highlights the following aspects:

$>$ Birla mandir cluster is the largest cluster, followed by Charminar cluster.

$>$ In all most all clusters majority of tourist spots are located within 200 meters buffer zone.

$>$ The concept of distance decay is visible to some extent in case of tourist places, i.e. the number of tourist spots decreased with an increase in distance.

Table 3:- Hyderabad - nearest tourist spot.

\begin{tabular}{|c|c|c|}
\hline Distance (in mt) & No. of tourist spots & \% \\
\hline$<500$ & 15 & 33 \\
\hline $500-1000$ & 8 & 17 \\
\hline $1000-2000$ & 8 & 17 \\
\hline$>2000$ & 15 & 33 \\
\hline Total & 46 & 100 \\
\hline
\end{tabular}


Fig 4:-

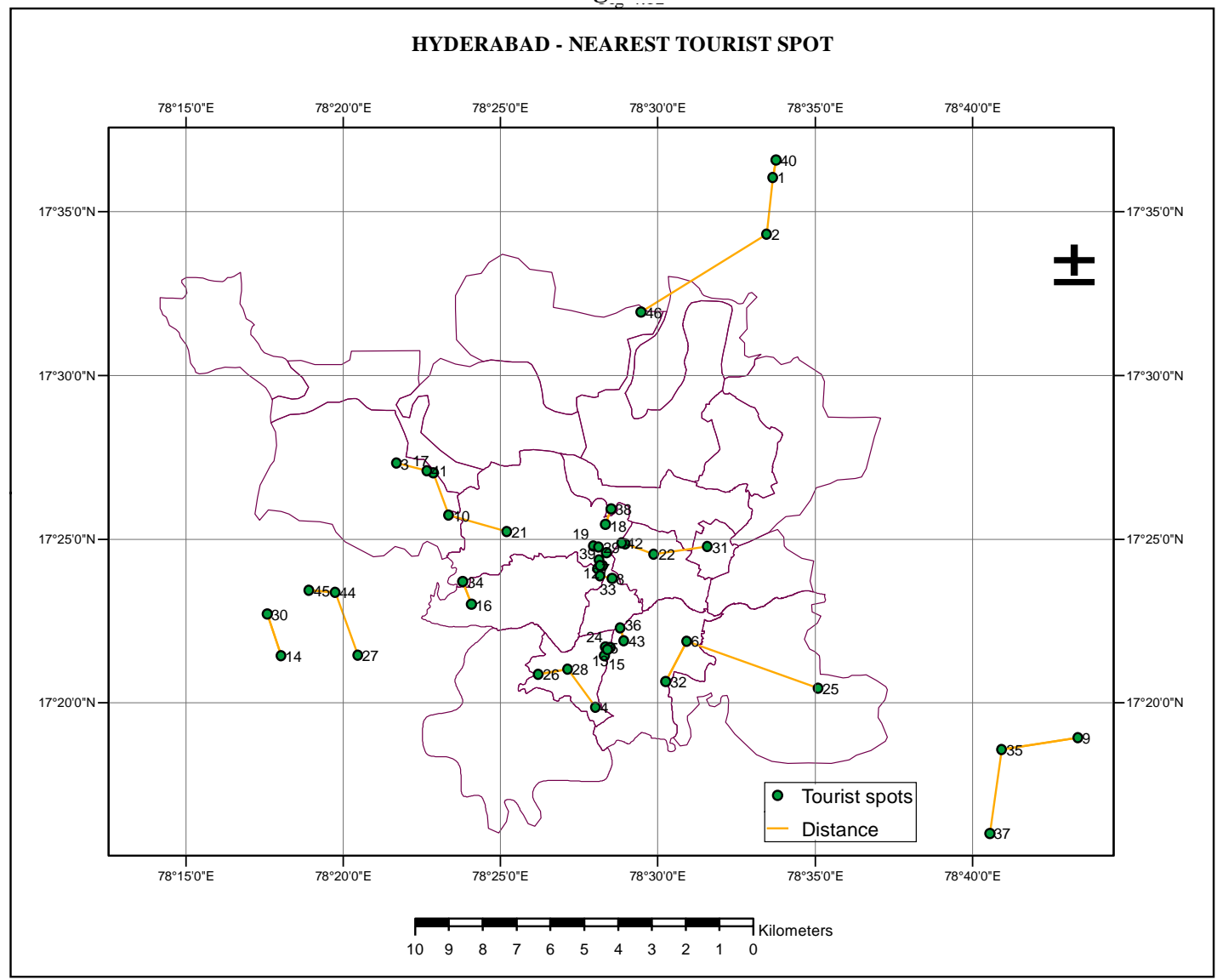

Source: Based on Data from Tourism Department, Government of Telangana

It is thus seen that, location visualization and characterization of tourist cluster provided large volume of information which is useful not only for the tourist, but also for tour operator, tourist planner, tourism department etc. Such type of analysis can be replicated in other urban tourist places.

\section{Conclusion:-}

An analysis of spatial distribution of historical monuments revealed that they are mostly associated with old historical core like Golconda and Charminar. Most of the historical spots are located in Hyderabad south in the vicinity of Charminar such as Chow Mahalla palace, Paigah tombs etc. The peri urban areas are devoid of historical monuments. The location of waterfront tourist spots revealed that, eventhough Hyderabad is endowed with numerous water bodies, 5 of them are recognized as water bodies with tourist attraction. Hussain sagar or tank bund is located with the heart of the city, Miralam tank and Osmansagar are the oldest tourist spots in Hyderabad. The urban periphery has also provided scope for waterfront tourist activity.

Maximum number of tourist spots is associated with Birla mandir cluster and least in Golconda fort cluster. Maximum number of tourist spots in almost in all the clusters is located within 200 meter buffer. While planning for tourism development, this aspect can be useful in planning circuits or tourist spot itenary to be taken into consideration by the tourism department and tour operators.

The city has diversified tourist spots. A large number of factors contributed to the growth tourist promotion in Hyderabad. Urban tourism is multifaceted in nature, in case of Hyderabad, the historical and cultural factors have emerged as the major drivers of tourist attractiveness. Technology made easy for the end tourist who can easily access the information and use this as an effective tool for visualization. 
This information is useful in the development of interactive website, information about tour package, tourist spots with photo gallery and tour circuits.

\section{Reference:-}

1. Deepthi, G. Geoinformatics with Web Application In Urban Tourism - A Case Study Of Hyderabad, thesis work of Ph.D, Department of Geography, Osmania University, Hyderabad, 2012

2. Graeme Evans. 2000 'Planning for Urban Tourism: A critique of Unitary Development Plans and Tourism Policy in London' International Journal of Tourism Research Volume 2, Issue 5, pages 307-326, September/October 2000

3. Mohamed R. Bualhamam, 2009, The study of urban growth impact in tourism area using remote sensing and GIS technique for north part of the UAE, Journal of Geography and Regional Planning Vol. 2 (6), pp. 166-175, June.

4. S.S. Fainstein, D.R. Judd 1999 Global Forces, Local Strategies and Urban Tourism D.R. Judd, S.S. Fainstein (Eds.), The Tourist City, Yale University Press, New Haven CT (1999), pp. 1-17.

5. Yong, K. S., and W. C. Gartner (2004). "Preferences and Trip Expenditures - A Conjoint Analysis of Visitors to Seoul, Korea." Tourism Management, 25 (1): 127-37.

6. Hyderabad Metropolitan Development Authority. http://www.hmda.gov.in/

7. Greater Hyderabad Municipal Corporation. http://www.ghmc.gov.in/

8. Incredible India, http://www.incredibleindia.org/ (official website of Ministry of Tourism, Government of India)

9. http://www.hyderabadtourism.in/

10. http://www.hyderabadtourist.com/hyderabad_attractions.html

11. http://www.hyd.co.in/category/attractions/ 